\title{
SETTING THE ANALYSIS OF NATURAL RESOURCE USE IN CONTINENTAL AREAS OF INDONESIA BY APPLICABILITY CONVENTION LAW OF PBB 1982
}

\author{
Munsharif \\ Lecturer of Unissula \\ Munsharif.abdul@gmail.com
}

\begin{abstract}
Before the entry into force of UNCLOS in 1982, the continental shelf area governed by Article 1 of the Convention IV Geneva Convention on the Law of the Sea in 1958, which was implemented a by Act No. 1 of 1973. The setting through 1958 Geneva Convention on the Law of the Sea benefit only for the developed countries that have the advanced technology. Although UNCLOS 1982 has been in force, but the status of Indonesian Act No. 1 of 1973 still impose as the implementation of the Geneva Conventions Of 1958. Several agreements with neighboring countries are being held between the years 196919972 , of course it is very detrimental to the Indonesian Government. In this case the Act No. 1 of 1973, adjusted to international law, namely UNCLOS in 1982 is expected that the regulating of the utilization of natural resources in the continental shelf of Republic Indonesia can provide a fair arrangement. It is Necessary to remember that there is a difference in perception between the Act No. 1 of 1973 with the UNCLOS in 1982 in the matter of setting the area of the continental shelf.
\end{abstract}

Keywords : Continental Shelf, The Value Of Justice, Utilization Of Natural Resources

\section{A. INTRODUCTION}

Under Article 1 of the Convention Montevideo with one of the establishment of a State is to have the region had its limits, and the region is the most important element for the establishment of a State. Against the State territory have rights to exercise sovereignty over the population and legal actions that occurred in the territory of that State. Defined in Act 43 of 2008, that region of Indonesia covering land, waters, seabed and subsoil beneath and the air space that is on it, including the natural resources contained therein. ${ }^{1}$ Furthermore, to the territorial waters of a coastal State comprises supplemental zone (zone contigous), exclusive economic zone, the continental shelf, and the high seas. Here is a cross-sectional images of the coastal State waters zone and division:

\footnotetext{
${ }^{1}$ Article 3 Act No. 43 of 2008 on the territory of the State.
} 


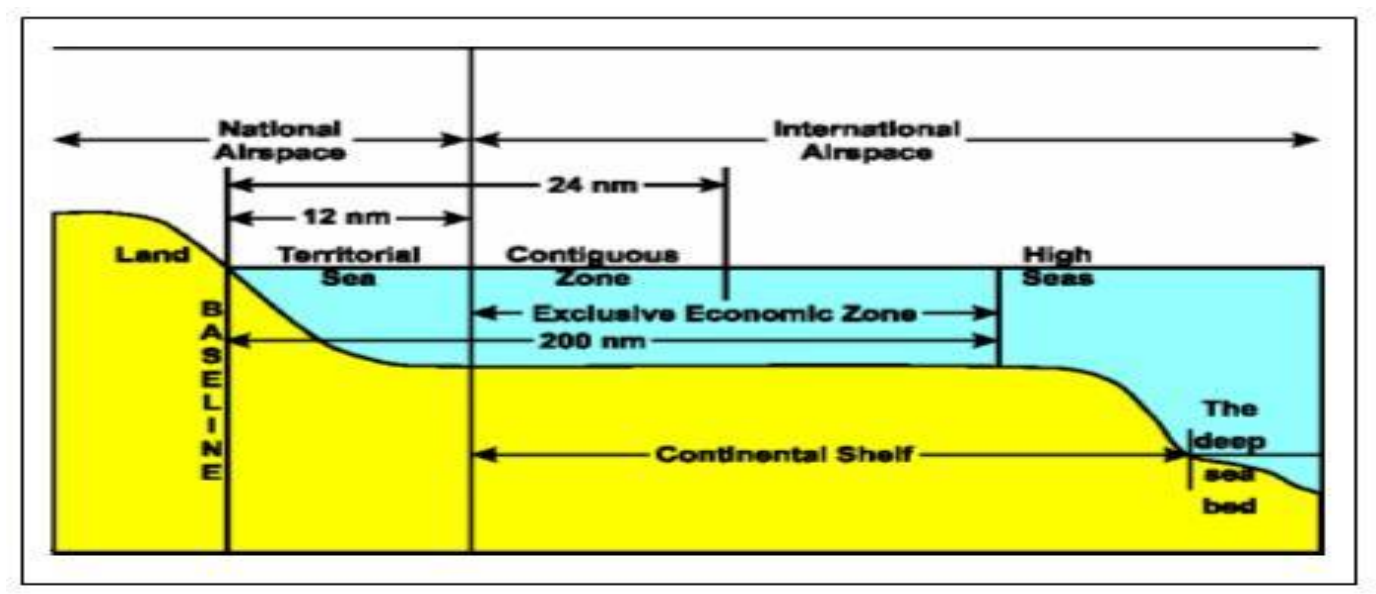

Figure 1 Maritime Zones
(Schofie1d, 2003: 18)

Explanation of the picture above as follows:

The yellow color is its land and continental shelf which is a continuation of the land area which is usually followed by the deep sea bed.

$>$ The color blue is water areas comprising territorial sea, contiguous zone, exclusive economic zone, and the high seas.

$>$ The white color is the area of water space, which consists of national air space and international air space.

To the territory of a State shall be clear and there should be certainty boundaries. Relating to borders proficiency level, for the State Indonesia the most urgent thing is to be immediately solved the sea areas, in which the territorial sea or territorial waters of Indonesia borders the 10 (ten) neighboring countries. The frontier encompass either a territorial sea, exclusive economic zone and continental shelf form. Indonesia maritime border with neighboring countries is still necessary to have the diselesikan to completion which can have the force of law and justice for all States, both countries are facing (opposte) with the Indonesian State and the State of adjoining (adjeacent) degan State of Indonesia. One is the issue of the continental shelf area settlement arrangement governed by international law or conventions currently in force. Indonesia has been implementing the Geneva Convention of 1958 by Act 1 of 1973 specifically on setting the continental shelf region, Indonesia has also ratified UNCLOS in 1982 through Act No. 17 1985. The ratification actions bring about legal consequences for the State Indonesia. This implies that Indonesia have entered into an international agreement, which is of course Indonesia should run all the rights and obligations, in accordance with the principles set out in international treaties, namely the principle of Pacta sunt servanda. Indonesia has been 
implementing the Geneva Convention of 1958 by Act 1 of 1973 specifically on setting the continental shelf region, Indonesia has also ratified UNCLOS in 1982 through Act No. 17 1985. The ratification actions bring about legal consequences for the State Indonesia. This implies that Indonesia have entered into an international agreement, which is of course Indonesia should run all the rights and obligations, in accordance with the principles set out in international treaties, namely the principle of Pacta sunt servanda. Indonesia has been implementing the Geneva Convention of 1958 by Act 1 of 1973 specifically on setting the continental shelf region, Indonesia has also ratified UNCLOS in 1982 through Act No. 17 1985. The ratification actions bring about legal consequences for the State Indonesia. This implies that Indonesia have entered into an international agreement, which is of course Indonesia should run all the rights and obligations, in accordance with the principles set out in international treaties, namely the principle of Pacta sunt servanda. The ratification actions bring about legal consequences for the State Indonesia. This implies that Indonesia have entered into an international agreement, which is of course Indonesia should run all the rights and obligations, in accordance with the principles set out in international treaties, namely the principle of Pacta sunt servanda. The ratification actions bring about legal consequences for the State Indonesia. This implies that Indonesia have entered into an international agreement, which is of course Indonesia should run all the rights and obligations, in accordance with the principles set out in international treaties, namely the principle of Pacta sunt servanda.

Indonesia as an archipelagic State does have legal certainty, according to both international law and national law. Viewed from the aspect of international law that has been set in the provisions laid down in the UN Law of the Sea Convention of 1982 (United Nations Convention on the Law of the Sea, which is abbreviated as UNCLOS 1982). In Article 308 (1) states that the Convention enters into force twelve (12) years after the convention was born, which is precisely the ratification of the 60th in 1994, meaning that in that year the convention has become effective. State-nagara actual actions or the international community can not be separated from the struggle of Indonesia in order to pass the position of Indonesia as an archipelagic State. Indonesia's struggle to get a position as an island nation finally gained the recognition of the international community. Indonesia talah ratified by attaching themselves to the UNCLOS in 1982 through Act No. 17 of 1985. 
It is necessary to get the attention, that Indonesia who have committed themselves to the UNCLOS 1982 can be used as a regulatory umbrella, so that in case of disputes with neighboring countries related to marine issues, particularly the issue of the area of the continental shelf, so the convention can be used as a foundation , Then come to the peak, that is, after Malaysia through its oil company, Petronas, awarded exploration rights to companies Shell for exploration in marine waters to the east of East Kalimantan named ND $6(\mathrm{Y})$ and ND $7(\mathrm{Z})^{2}$

International law which mostly arise from countries in Western Europe is a legal system of society or nations that the concepts and principles of prnsip the law derived from national legal systems, which have since emerged from the concept or system of Roman law, and thrive through international customs as a source. National law that has universal values acceptable to the international community that can be used as a principle or rule of law. Indonesia as an archipelagic State does have the power or the rule of law, both in terms of international law and national law. By herarkhi between international law and national law gave birth to two different viewpoint, namely: The first view or understanding of monism with the primacy of national law which states that international law is a continuation of a national law or international law is none other than national laws for foreign affairs. The second is the view or understanding of monism with the primate / primacy of international law, which states that national law is subject to international law which is a delegation of authority of international law. ${ }^{3}$ It is expected that the role of the national law may provide concepts or principles of international law as contribute ideas for the development of international law.

Theoretical and practical international legal relations with national laws often lead to various problems (The question of the relationship between international law and national law can give rise to many practical problems, especially if there is a conflict between international law and national law). Two things to note in the harmonization of the laws is to harmonize the regulatory system (policy formulation) and harmonization in substance (matter). HOW first step harmonization formulation of the legal system, and secondly how the formulation step harmonization of legal materials (norms).

There are two views about the submission of international law, the first view of voluntarism, which bases the entry into force of international law or international law

\footnotetext{
${ }^{2}$ Amad Sudiro dan Deni Bram; 2013, Hukum dan Keadilan Aspek Nasional dan Internasional, RajaGrafindo Persada, Jakarta, p. 101

${ }^{3}$ Soekotjo Hardiwinoto; 1994, Pengantar Hukum Internasional, Penerbit Undip, Semarang, p. 80.
} 
whether or not there on a whim countries. Both views objectivism, which considers the existence or enactment of international law regardless of the willingness of the state. The existence of different views have resulted in the emergence of a different viewpoint, where the view voluntarism would violate international law and national law as two legal devices coexist and separate, while the view of objectivism think of it as two parts of a single legal instrument, closely related to herarki legal issues between the two devices that law. In addition to the two foregoing view there are two streams or teaching that explains the relationship of international law with national law, namely the flow of monism and dualism flow. The monistic persuasion assert that international law and municipal law are two aspects of one system; dualists regard the two as separate and coordinate system. Monist Differ as to the which of the two is to be ragarded as supreme, while dualists see Reviews their relationship as one of coordination. ${ }^{4}$

Flow monism says that international legal relationship with national law are two aspects of the same from one system of law in general. According to the flow of all legal monism is a unit that has no binding force both to the individual, the state and subjects of international law. Next is the flow of dualism, explained that international law with national law are two different legal system altogether. Proponents of this flow is Triepel and Anzelotti, which states that international law and national law respectively represent two different legal systems and terpisash one another, these differences exist in the legal sources, subject to legal and legal force. In the application of international law into national law there is the theory of transformation,

Since no doctrinal position seems to encompass all the facts, it is Likely that this controversy will continue indefinitely. Practice suggests that, infact, a mixture of supremacy of international law, municipal law supremacy, and coordination of legal systems exists. When, for example, an international tribunal finds that municipal law conflict with international law, it will override the municipal law, ${ }^{5}$ As long as there is no doctrine that includes all of the facts, there is a possibility that the controversy international law with national law will continue, which in practice shows that in fact, the rule of international law by national law in the legal system problems will remain. As in the

\footnotetext{
$\left.{ }^{4}\right)$. Edward Collins, Jr; 1970, International Law in a Changing World, Casees, Documents, and Readings, Printed and bound by Halliday lithograph Corporation, West Hanover, Mass, Random House New York, Manufactured in the United States of America, p. 45.

${ }^{5}$ Greco-Bulgarian Communities "Advisory opinion of the Permanent Court of International Justice", 1930, the which the Court stated: international law that in the relations between powers who are contracting parties to a treaty.
} 
existing legal system when, for example, an international court found that the national law conflicts with international law, it will override national law.

It is in the practice of national courts that the relationship of international law to municipal law is of fundamental importance. Lacking adequate enforcement device of its own, the international community must Rely largely upon the governmental organs of the separate states to give effect to its norms, ${ }^{6}$ In the practice of the national court that the international legal relationship with national law is crucial. The lack of adequate law enforcement devices owned by the international community would have to rely mostly on government organs of various countries to give effect to the norm.

Indonesia is an archipelago (archipolagic state) in the world. Indonesia has a number of 17503 islands, with a coastline of $81290 \mathrm{~km}$ and 5.8 million sq km area as the largest archipelago in the world, Indonesia has a marine area of approximately two-thirds of the entire national territory. The total area of Indonesian waters which 5.8 million square kilometers itemized as follows: marine area of 0.3 million square kilometers, the archipelagic waters covering an area of 2.8 square kilometers, and the exclusive economic zone of 2.7 square kilometers. Apart from that, the Indonesian archipelago has a very strategic position, as it is located between the continents of Asia and Australia, and is flanked by the Indian Ocean and the Pacific Ocean. In addition to having a very broad water area, Indonesia is also a country that is rich in potential and diversity of natural resources, both natural resources and non-biological. Meanwhile, because of its strategic position, the Indonesian archipelago has become a very important shipping passage to connect economic activity between countries in different parts of the world.

In addition to the potential for oil and gas riches contained in the seabed and subsoil around the islands only part of it that has been explored and exploited. Condition as described above is a result of international recognition of the status of Indonesia as an archipelagic country.

The term status as the island nation has been listed in Article 46 Section IV of the UN Convention on the Law of the Sea (United Nations Convention on the Law of the Sea; UNCLOS 1982), (Use of terms), which states For the purposes of this Convention:

\footnotetext{
${ }^{6}$ MacLeod v. United 'States, (1930), the statute should be construed in the light of the purpose of the Government to act within the limitation of the principles of international law, the Observance of the which is so essential to the peace and harmony of nations (Law of must be interpreted clearly about the purpose of government to act within the limits of the principles of international law, and adherence to the principles of tersbut so important to the peace and harmony of nations).
} 
(a) "archipelagic State"means a state constituted wholly by one or more archipelagos and may include other islands;

(b) "archipelago"means a group of islands, Including parts of islands, interconecting waters and other narural features roomates are so closely interconected that such islands, waters and othe natural features form an intrinsic geographical, economic ande political entity, or whjich historically have been regarded as such. $^{7}$

UN Convention on the Law of the Sea has been ratified by Act No. 17 of 1985 on the affirmation of the UN Convention on Law of the Sea. Thus, the sovereignty and the sovereign rights and jurisdiction of the Republic of Indonesia on the water chamber and all natural resources contained in sea surface and the air above it, in the water column and on the sea floor and the ground beneath it has been recognized by international law. Therefore, there are opportunities as possible to be used for the improvement of the welfare of all the people of Indonesia.

The legal action in the form of ratification of the UN Convention on the Law of the Sea 1982 is not yet supported by the Indonesian government's significant efforts in other areas to protect national territorial waters and its potential enormous natural wealth. In this case still requires the development of national laws in order to support the existence of the Republic of Indonesia in the sea area. Development of national law in this regard include legal materials, legal structure, legal culture and infrastructure arrangement and enforcement. Legal material development is an ongoing process in line with developments in science and technology. The development of national law must be consistent with the change of relations between countries in international fora. Changes in the structure of relationships between countries is marked by the birth of a new agreement through various forms of rule changes in the scope of bilateral, regional, and international. At the national level regulatory material change legislation in the maritime field are also required to comply with the new developments introduced by the UN Convention on the Law of the Sea, 1982. One of the areas of maritime law that need to be adjusted to the new provisions in the Law of the Sea Convention is Act No. I of 1973 on Indonesian Continental Shelf. In other words, the Act Indonesian Continental Shelf was born 21 years before the UN Convention on the Law of the Sea apply formally in 1994. At the national level

\footnotetext{
${ }^{7}$ Albert W. Koers, 1991, Konvensi Perserikatan Bangsa-Bangsa Tentang Hukum Laut, Gajah Mada University Press, Yogyakarta, p.117
} 
regulatory material change legislation in the maritime field are also required to comply with the new developments introduced by the UN Convention on the Law of the Sea, 1982. One of the areas of maritime law that need to be adjusted to the new provisions in the Law of the Sea Convention is Act No. I of 1973 on Indonesian Continental Shelf. In other words, the Act Indonesian Continental Shelf was born 21 years before the UN Convention on the Law of the Sea apply formally in 1994. At the national level regulatory material change legislation in the maritime field are also required to comply with the new developments introduced by the UN Convention on the Law of the Sea, 1982. One of the areas of maritime law that need to be adjusted to the new provisions in the Law of the Sea Convention is Act No. I of 1973 on Indonesian Continental Shelf. In other words, the Act Indonesian Continental Shelf was born 21 years before the UN Convention on the Law of the Sea apply formally in 1994. One of the areas of maritime law that need to be adjusted to the new provisions in the Law of the Sea Convention is Act No. I of 1973 on the Indonesian Continental Shelf. In other words, the Act Indonesian Continental Shelf was born 21 years before the UN Convention on the Law of the Sea apply formally in 1994. One of the areas of maritime law that need to be adjusted to the new provisions in the Law of the Sea Convention is Act No. I of 1973 on the Indonesian Continental Shelf. In other words, the Act Indonesian Continental Shelf was born 21 years before the UN Convention on the Law of the Sea apply formally in 1994.

However, insofar as the sovereign rights of the Republic of Indonesia on the sources of the seabed's natural wealth, especially oil and gas, continental shelf legislation has been strengthened with the enactment of Act No. 5 of 1983 on the Exclusive Economic Zone (EEZ) of Indonesia. In accordance with the provisions of the UNCLOS 1982, legislation EEZ have set up sovereign rights of the Republic of Indonesia kekayaana sources of biological and non-biological up to 200 nautical miles measured from the baselines of the islands of Indonesia. Thus the judicial utilization of all natural resources contained in the seabed and subsoil beneath it juridically already have a legal basis in the two laws simultaneously, namely: the Continental Shelf Act and the Law on the Exclusive Economic Zone.

Meanwhile, the United Nations Law of the Sea Convention of 1982 establishes various criteria as an alternative to fixing the outer limit of the continental shelf that can be claimed by the coastal State. Under the provisions of Article 76, any coastal state can choose the most favorable alternative, whether to use horizontal criteria or the distance 
from the base line, vertical criterion or criteria of depth and the thickness of seabed sediments as evidence of a natural connection with the mainland (natural prolongation). Whatever the chosen criteria is not allowed coastal states to claim more daari continental shelf of 350 nautical miles from the baselines used to measure the width of the sea territory. This provision can be used to open up opportunities for any coastal state, including Indonesia, to set the boundaries of the continental shelf more than 200 nautical miles. Opportunities for the determination of the continental shelf area of more than 200 nautical miles would be open if Indonesia is able to put forward arguments based on the scientific evidence that was not disputed by other countries, and can convince the General Secretariat of the United Nations. Therefore, changes to Act No. 1 of 1973 on the continental shelf can only be done if supported by the evidence of nature. In this case, Indonesia has conducted scientific research on seabed conditions conducted by various agencies to support Indonesia's claim to the territory of the continental shelf beyond 200 nautical miles, measured from the baselines of the islands, especially in the Indian Ocean and the Pacific Ocean. Furthermore, the results of these studies should be followed by an attempt by the law of equivalent legislation as justification. Therefore, Act No. 1 of 1973 which is still based on the Convention on Law of the Sea Geneva 1958 needs to be amended and adapted to perkembanghan new suit UNCLOS 1982, especially with regard to the determination of the outer limit of the area of the continental shelf, the demand for immediately to amend national legislation. Obviously in this case required the scientific justification in the form of an academic paper on the draft legislation to amend the provisions concerning the continental shelf area of Indonesia. Therefore, Act No. 1 of 1973 which is still based on the Convention on Law of the Sea Geneva 1958 needs to be amended and adapted to perkembanghan new suit UNCLOS 1982, especially with regard to the determination of the outer limit of the area of the continental shelf, the demand for immediately to amend national legislation. Obviously in this case required the scientific justification in the form of an academic paper on the draft legislation to amend the provisions concerning the continental shelf area of Indonesia. Therefore, Act No. 1 of 1973 which is still based on the Convention on Law of the Sea Geneva 1958 needs to be amended and adapted to perkembanghan new suit UNCLOS 1982, especially with regard to the determination of the outer limit of the area of the continental shelf, the demand for immediately to amend national legislation. Obviously in this case required the scientific justification in the form of an academic paper on the draft legislation to amend the 
provisions concerning the continental shelf area of Indonesia. the demand for an immediate change in national legislation. Obviously in this case required the scientific justification in the form of an academic paper on the draft legislation to amend the provisions concerning the continental shelf area of Indonesia. the demand for an immediate change in national legislation. Obviously in this case required the scientific justification in the form of an academic paper on the draft legislation to amend the provisions concerning the continental shelf area of Indonesia.

Birth of the UNCLOS 1982 that once the enactment of the provisions of the new law of the sea, then Indonesia is an archipelago which is seen as a unified whole between the islands and waters. ${ }^{8}$ Two-thirds, or approximately $70 \%$ of Indonesia consists of the sea, the rest of which is one-third, or approximately $30 \%$ consists of land or earth, that it contains a variety of natural resources. Management of natural resources in the mainland is done to excess, thus experiencing a critical point for the reserves of natural resources into the future. To resolve this issue needs to be born an empowerment of the territorial sea as a source of livelihood of the nation as well as the support of foreign exchange. What is more interesting is the discovery of non-biological resources, previously unthinkable, such as minerals, natural gas and petroleum. ${ }^{9}$

We are aware of the sea was rich in mineral mining goods priceless, which is expected to be able to meet the needs of the world if mineral resources on land are not sufficient or completely empty. This encourages coastal states, including Indonesia for the exploration and exploitation of sea areas including the area of the continental shelf jurisdiction. Source of wealth that is in the sea areas and particularly in the area of the continental shelf is so big and if managed and fully utilized will likely improve the welfare of mankind in this world. Not only the Republic of Indonesia, but also approximately $70 \%$ of the total surface area of the earth is made up of the sea, and in addition to the vast percentage is a reality, ${ }^{10}$ Therefore, the existence of potential wealth of resources at sea and on the seabed and the land beneath the continental shelf desebut as you need further adjustment, either through international law and national law.

We can not deny that the development of law in Indonesia, especially in the construction of legal materials (legal substance) until today is still far from expectations to

\footnotetext{
${ }^{8} \mathrm{ST}$ Munadjat Danusaputro; Kawasan Baskom Pasifik Menghadapi Gelombang Perkembangan Internasional: Pengembangan Studi Wilayah Kawasan Asia Pasifik (Bunga Rampai), p. 148.

${ }^{9}$ John Pieres, 2001, Pengembangan Sumberdaya Kelautan, Pustaka Sinar Harapan, Jakarta, p. 5-6

${ }^{10}$ Frans E, Likadja dan Daniel F Bessie; 1988, Hukum Laut dan Undang-Undang Perikanan, Ghalia Indonesia, Jakarta, p. 10.
} 
meet the needs and aspirations of the people of Indonesia. In the implementation of the plan and quantitative formation is more prominent than the consideration of quality of legislation issued, On the other hand to Achieve Common needs someone actually doing is reprehensible. Both in the field of trade and nor in any field where people are doing business. ${ }^{11}$ The number of regulations issued was also not followed by steps pengharmonisasian, especially in legislation results from pengadobsian international law or international conventions, both at the time of the draft legislation is still under discussion at the internal level and at the level of external , In accordance with the basic values of law, of course, necessary to pengharmonisasian legislation or laws, regional, national or international level, where the need for pengharmonisasian between national law and international law, or vice versa. Based on the above-mentioned background.

\section{B. RESULT AND DISCUSSION}

- Natural Resource Utilization Settings In Continental Area of Indonesia By Applicability UNCLOS 1982

The continental shelf is the seabed which, when viewed in terms of geology and geomorphology is a continuation of the continent or the mainland. Continental shelf depth of no more than 200 meters. Boundaries of the continental shelf measured from the base line to the outside with a coast the farthest distance is 200 miles or more while it is possible to do exploration and exploitation of natural resources in the region. If there are two states side by side (adjacent) or opposite in a single landing sea mengusai kontien and the distance is less than 400 miles, the limit of the continental shelf area of each country drawn equidistant from each base line. This is the state's obligation does not interfere with shipping traffic peace in the continental shelf.

The continental shelf is the seabed geological and geomorphological is a continuation of a mainland continent. Sea depth of no more than 200 meters. Indonesia is located on the continental shelf two, namely the Asian continental shelf and the continental shelf of Australia. The limits of the continental shelf is measured from the baselines, which is the most distant 200 nautical miles. If there are two or more countries to master the seas on the continental shelf, then the

\footnotetext{
${ }^{11}$ Andri Winjaya Laksana, "CYBERCRIME COMPARISON UNDER CRIMINAL LAW IN SOME COUNTRIES,"
} Jurnal Pembaharuan Hukum V, no. 2 (2018): 217-26. 
country's borders drawn equidistant from baseline in each country. For example in the Strait of Malacca, the continental shelf boundary coincides with the boundary of the territorial sea, because the distance between the two countries where it is less than 24 nautical miles. In the Strait of Malacca to the north, the continental shelf boundary between Thailand, Malaysia, and Indonesia met near point coordinates 98 ${ }^{\circ} \mathrm{E}$ and $6^{\circ} \mathrm{N}$. Inside the boundary line of the continental shelf, Indonesia has the authority to use the natural resources that exist in it, with the obligation to provide a peaceful cross shipping lanes. The announcement of the continental shelf boundary was issued by the Government of Indonesia on 17 February 1969.

\section{- Natural Resources in the Continental Shelf}

To observe the development and establishment of marine law including the problems of the continental shelf region setting, it would require a study and analysis of the interests underlying attitudes of the country as a member or part of the international community. ${ }^{12}$ Countries emerging will try to control the sea to the expansion of jurisdiction to protect its interests, especially the advancement of technology is more advanced, more dense population of the world, and the increasing needs of mankind in every country to encourage their desire to take advantage of natural resources will be able to provide benefits for a country to the welfare of the nation. Therefore, to implement a set desires and interests of countries at international level, and also in order to avoid overlap between these interests, the established conventions of international maritime law. After going through various stages held a conference on law of the sea, forming the Hague Convention on Law of the Sea of 1930,

At first the continental shelf only has meaning only geographically and geologically. Geographically and geologically interpreted Continental Shelf as plateform or seabed area which is located between the shallow sea floor and the point where the sea floor or steep declines sharply, which is called the continental slope. One of the countries that had ratified the UNCLOS 1982 is Indonesia. Indonesia is the largest archipelago in the world that has been endorsed by the United Nations through the United Nations Law of the Sea Convention of 1982 (UNCLOS 1982) and has been recognized internationally. Indonesian state consists of approximately

\footnotetext{
${ }^{12}$ Ramlan, 2006, Hukum Laut Internasional, Universitas Jambi, Jambi, p. 28.
} 
17,548 islands with a total area of 7.7 million square kilometers, and consists of 1.9 million square kilometers of land area, 5.8 million square kilometers of ocean territory form. In other words Indonesian sea area is three times the area of the land. Therefore it is fitting for the Indonesian government needs to give special attention in terms of determining the maritime boundaries with countries bordering with Indonesia, especially related to the boundaries of the continental shelf, because it concerns the security, backup, and utilization rather than source -source seabed mineral wealth and land beneath it, called the continental shelf, such as setting the maritime boundaries Indonesia and Malaysia, Singapore, Thailand, India, Papua New Guinea, Australia, Vietnam, the Philippines, and Palau.

Today, natural resource management oriented land areas which include forestry resources, mining, oil and gas and plantation. Management of natural resources in the sea areas not yet optimal. The issue of management of natural resources in the sea only in the form of illegal fishing and tenure conflicts catchment area of marine products among fishermen. Although the discourse of a sea area has been established, but the issue of natural resource management, especially in the continental shelf still neglected.

According to Mochtar Kusumaatmadja, said in addition to the sedentary over sentary extant species of living organisms, for example, seaweed and other vegetation, sponges, corol enichoderm, mollucs. For natural resources that can not be refurbished are contained in the subsoil of the seabed according to the type of coating consists of:

- continental shelf namely petroleum, natural gas, sulfur, mineral water, coal, diamonds;

- continental slope is phosphorus;

- abbysal plain and the deep ocean floor there is a $25 \%$ manganese, $15 \%$ iron, cobalt, nickel, copper.

As we know, a large part of Indonesia seabed holds the potential of minerals in the form of gold, silver, timble, tin, copper, nickel, oil and gas $70 \%$ of the oil and gas basins. Indonesia is estimated to have approximately 60 basins. It contains petroleum potential estimated at nearly 9.1 billion barrels. Average natural gas potential of 230 trillion cubic feet equivalent. It is a great potential for us to be able dimemanfaatkan Indonesian nation and managing natural resources existing in the 
sea, on the continental shelf of governance for the benefit of its citizens who live near the coast. ${ }^{13}$

The concept was introduced by the continental shelf of the United States first on the Law of the Sea Convention in 1958. The filing it as a strategy in the face of the island nations that proposed the concept of an archipelago, and in order to facilitate the business interests of his country to explore non-living natural resources (oil and gas) are potentially found in the continental shelf. The problems that exist, because due to lack of clarity on the concept of the continental shelf UNCLOS I in 1958. Through UNCLOS I in 1958 or the Geneva Convention on Law of the Sea of 1958 special issue of the continental shelf region settings Indonesia ratified by Act No. 1 of 1973 . Then with the entry into force of the Convention III 1982 Law of the Sea or UNCLOS 1982, the continental shelf issue as one of the important agenda. United Nations Convention on Law of the Sea (UNCLOS-United Nations Convention on the Law of the Sea) III, has given a recognition on Indonesia in the form of the island nation. This international recognition, followed by the promulgation of Act No. 171985 on the Ratification of the UN Convention on Law of the Sea, 1985. Since the enactment of this law on December 31, 1985, Indonesia is bound in the UNCLOS 1982 (UNCLOS 1982). This recognition is very important for Indonesia, which has the most islands in the world, masala that is, how the management of existing resources can be a member of a well-being for people around the beach. has given a recognition on Indonesia in the form of the island nation. This international recognition, followed by the promulgation of Act No. 171985 on the Ratification of the UN Convention on Law of the Sea, 1985. Since the enactment of this law on December 31, 1985, Indonesia is bound in the UNCLOS 1982 (UNCLOS 1982). This recognition is very important for Indonesia, which has the most islands in the world, masala that is, how the management of existing resources can be a member of a well-being for people around the beach. has given a recognition on Indonesia in the form of the island nation. This international recognition, followed by the promulgation of Act No. 171985 on the Ratification of the UN Convention on Law of the Sea, 1985. Since the enactment of this law on December 31, 1985, Indonesia is bound in the UNCLOS 1982 (UNCLOS

\footnotetext{
${ }^{13}$ Pengelolaan SDA di Landas Kontinen Indonesia dalam http://dokumen.tips/documents/pengelolaan-sda-dilandas-kontinen-indonesia.html, Accessed on Sunday, 27-3-2016, 21:10 o'clock.
} 
1982). This recognition is very important for Indonesia, which has the most islands in the world, masala that is, how the management of existing resources can be a member of a well-being for people around the beach. Since the enactment of this law on December 31, 1985, Indonesia is bound in the UNCLOS 1982 (UNCLOS 1982). This recognition is very important for Indonesia, which has the most islands in the world, masala that is, how the management of existing resources can be a member of a well-being for people around the beach. Since the enactment of this law on December 31, 1985, Indonesia is bound in the UNCLOS 1982 (UNCLOS 1982). This recognition is very important for Indonesia, which has the most islands in the world, masala that is, how the management of existing resources can be a member of a well-being for people around the beach. ${ }^{14}$

The UN Convention on Law of the Sea 1982 (UNCLOS 1982-United Nations Convention on the Law of the Sea) III in 1982, has given an acknowledgment in Indonesia in the form of the island nation and has given the criteria on the definition of the continental shelf area that would meet the elements of justice. This international recognition, followed by the promulgation of Act No. 17 of 1985 on the Ratification of the UN Convention on Law of the Sea Of 1982. Since the enactment of this law on December 31, 1985, Indonesia is bound in the UNCLOS 1982 (UNCLOS 1982). This recognition is very important for Indonesia, which has the largest island in the world, the existing problems.

\section{- The setting of the Continental Shelf}

Indonesia and nations in any corner of the earth, now connected and coopted into a pattern of life. As a result, the territorial boundaries of national states is almost no longer a barrier to the development of a variety of human activities. The tendency to live together is a natural human instinct. Therefore, with the formation of the United Nations Law of the Sea Convention, 1982, may be a few examples of the merging tendencies in the life pattern of similar interests. In such circumstances, the norms regulating the activity variance would not be submitted to the normative rules of a particular country. Because the rules of national law of a sovereign state, limit the entry into force only in the territory of the country.

\footnotetext{
${ }^{14}$ Ibid.
} 
Therefore, ${ }^{15}$ or international conventions. The instrument is the most likely to be used in addressing transnational issues or problems between nations faced together. On the condition of the world community described the sort, a legal instrument of international treaties", increasingly becoming important. Through an international agreement that states, either making a deal or countries that participated then, can create norms of the new law is needed to regulate the relationship between countries and between the public countries that volume is greater, the intensity is getting stronger, and the material increasingly complex, ${ }^{16}$ so as to create harmony arrangements or legal harmonization between these countries based on justice. Based on the reality of an increasingly unified world community, some interesting things to study, among other things how the process of nationalization" ${ }^{\prime 17}$ in toward the harmonization of national law with international law that justice can be realized, especially in the regulation of natural resource use in the area of the continental shelf with the entry into force of UNCLOS Of 1982. Further international cooperation in law what kind of Indonesia that has been done with other countries in the management arrangements natural resources in the area of the continental shelf, so it should be used as a model reciprocal agreement that deserves to be pursued in order to create a harmonious atmosphere in the future. When sovereign states want to make a deal about anything with regard to the interests of the state and the nation between them, usually that norms are made on the basis of mutual agreement with the objectives and consequences of a particular law,

${ }^{15}$ The international agreements are agreements concluded between the members of the community of nations and aims to result in certain legal consequences. In the theory of international law, international treaties are distinguished into two classes, namely: (1) law making treaties and (2) contracts treaty. Law making treaties is an international agreement containing the rules of law which can be applied universally to members of the community of nations, and thus can be categorized as an international treaty that serves as a direct source of international law. While the contracts teraty is an international treaty that governs relations or specific issues between the parties which manage it alone, so that such an international agreement specifically applies only to the participants of the agreement. Anyway treaty contracts do not directly become a source of international law. Read Mochtar Kusumaatmadja, Introduction to International Law. Bandung: Binacipta, 1978, p. 109, 114, and 115. Bdgk. JG Starke, Introduction to International Law. London: Butterworths, 1984, p. 40-44.

${ }^{16}$ See Mochd.Burhan Tsani, 1990, Hukum dan Hubungan Internasional, Liberty, Yogyakarta, p. 8-9.

${ }^{17}$ Indonesian dictionary describes the meaning of nationalization as a process of making something to belong to a nation or state (mainly foreign-owned), which is usually followed by the replacement of which is compensation. But the use of the word 


\section{CLOSING}

\section{- Conclusion}

The continental shelf is the seabed and land area underneath which is a continuation waiayah land, which is outside the territorial waters the depth of water in it does not exceed 200 meters. Where the region is abundant in natural resources such as minerals, oil and natural gas. So that this region into an area of high potential for coastal states setting the boundaries of the continental shelf in accordance with the Geneva Convention on Law of the Sea of 1958, which has diadobsi by Act No. 1 In 1973, the particulars of the continental shelf mengutungkan only developed countries that the technology is already advanced. Where this article provides depth and capability criteria, so it needs to be reconstructed with Article 76 of the UN Convention 1982 which provides minimum and maximum distance criteria. Indonesia as a developing country between 1969 to 1972 Sempai has entered into an agreement on the continental shelf boundary agreements with neighboring countries whose territory borders and the adjacent face. Agreements agreed upon in the very detrimental to Indonesia, particularly the agreement made with the State Australia wide sea area between the two countries 360 nautical miles. In which Indonesia gets 60 miles northwest, was Autralia acquire up to 300 nautical miles. With the entry into force of UNCLOS 1982 has been ratified by Act No. 17 In 1985, the Indonesian government needs to review the settlement agreement the limits of the territorial sea,

\section{BIBLIOGRAPHY}

Agus Sudrajat dalam LD Mirfan Zaeland, 2016, Analisis Yuridis Pengelolaan Keuangan Desa Berdasarkan Undang-undang Nomor 6 tahun 2014 (studi di Desa Bangkali Barat, Kecamatan Watopule Kabupaten Muna), Skripsi.

Albert W. Koers, 1991, Konvensi PerserikatanBangsa-Bangsa Tentang Hukum Laut, Gajah Mada University Press, Yogyakarta.

Ali Mansyur, 2010, Pranata Hukum \& Penegakkannya di Indonesia, Unissula Press, Semarang.

Amad Sudiro dan Deni Bram; 2013, Hukum dan Keadilan Aspek Nasional dan Internasional, RajaGrafindo Persada, Jakarta. 
Edward Collins, Jr; 1970, International Law in a Changing World, Casees, Documents, and Readings, Printed and bound by Halliday Lithograph Corporation, West Hanover, Mass, Random House New York, Manufactured in the United States Of America.

Frans E, Likadja dan Daniel F Bessie; 1988, Hukum Laut dan Undang-Undang Perikanan, Ghalia Indonesia, Jakarta.

Gunarto, 2011, Rekonstruksi konsep Kebebasan Berserikat Melaui Serikat Pekerja Pada Hubungan Industrial Berbasis Nilai Keadilan Menuju Kesejahteraan Pekerja (Ringkasan Disertasi), Program Doktor Ilmu Hukum Undip Semarang.

Greco-Bulgarian "Communities" advisory opinion of the permanent Court of International Justice, 1930, which the Court stated : international law that in the relations between powers who are contracting parties to a treaty.

Hassan Shaddily, dkk.; Ensiklopedi Indonesia, Edisi Khusus, HAN/KOL, Ichtiar Baru Van Hoeve, Jakarta.

John Pieres, 2001, Pengembangan Sumberdaya Kelautan, Pustaka Sinar Harapan, Jakarta.

Laksana, Andri Winjaya. "CYBERCRIME COMPARISON UNDER CRIMINAL LAW IN SOME COUNTRIES." Jurnal Pembaharuan Hukum V, no. 2 (2018): 21726.

M. Dahlan Al-Barry, 1995, Kamus Modern Bahasa Indonesia, Arkola, Yogyakarta.

Ramlan, 2006, Hukum Laut Internasional, Universitas Jambi, Jambi.

Soekotjo Hardiwinoto; 1994, Pengantar Hukum Internasional, Penerbit Undip, Semarang. 